\title{
PENGARUH PERSEPSI SISWA TENTANG KEMANDIRIAN BELAJAR DAN KELENGKAPAN FASILITAS BELAJAR TERHADAP PRESTASI BELAJAR MATEMATIKA
}

\author{
Uta Selwanti Ridwan ${ }^{1}$ \\ Unversitas Cokroaminoto Palopo ${ }^{1}$ \\ utaselwati@gmail.com ${ }^{1}$
}

\begin{abstract}
Abstrak
Penelitian ini bertujuan untuk mengetahui pengaruh persepsi siswa tentang kemandirian belajar dan kelengkapan fasilitas belajar terhadap prestasi belajar matematika siswa di SMP Negeri 1 Kalaena Kiri Kabupaten Luwu Timur. Penelitian ini dilaksanakan pada siswa kelas VII sebanyak 83 responden. Metode pengumpulan data menggunakan angket dan nilai raport. Sedangkan metode analisis data meliputi analisis deskriptif dan analisis regresi berganda. Hasil penelitian menunjukkan: 1) Pengaruh positif dan signifikan antara kemandirian belajar terhadap prestasi belajar matematika siswa kelas VII, dan 2) Pengaruh positif dan signifikan antara kelengkapan fasilitas belajar di sekolah terhadap prestasi belajar matematika siswa kelas VII SMP Negeri 1 Kalaena Kiri.
\end{abstract}

Kata Kunci: Kemandirian Belajar dan Kelengkapan Fasilitas Belajar

\section{A. Pendahuluan}

Pada era globalisasi seperti sekarang ini, pendidikan menghadapi tantangan yang sangat kompleks. Salah satu permasalahan yang dihadapi adalah usaha meningkatkan mutu pendidikan dan meningkatkan kualitas manusia, agar bisa bersaing dengan negara-negara maju. Dalam rangka meningkatkan mutu pendidikan, pemerintah telah menetapkan beberapa kebijakan, diantaranya yaitu mengadakan pembaharuan kurikulum dari tingkat dasar, tingkat menengah sampai tingkat atas. Dikeluarkannya Undang-undang No. 20 tahun 2008 tentang guru dan dosen, yang di dalamnya memuat tentang upaya pemerintah untuk terus meningkatkan kesejahteraan para guru dan dosen serta usaha untuk meningkatkan kualitas dan profesionalitas para tenaga pendidik. Kebijakan yang lainnya adalah adanya program pendidikan sembilan tahun untuk meningkatkan kesadaran masyarakat akan pentingnya pendidikan. Diharapkan dengan usaha pemerintah tersebut kegiatan belajar mengajar dapat ditingkatkan, sehingga mutu pendidikan pun dapat meningkat secara bertahap. 
Pendidikan dapat ditempuh melalui tiga jalur yaitu: pendidikan formal, pendidikan informal, dan pendidikan non formal. Proses pembelajaran yang dilakukan di sekolah merupakan aplikasi dari pendidikan formal. Melalui sekolah siswa disiapkan dapat mencapai perkembangan pemahaman suatu kompetensi secara optimal. Secara umum, keberhasilan proses belajar siswa dipengaruhi oleh dua faktor, yaitu faktor internal dan faktor eksternal. Faktor internal meliputi:

1. Faktor fisiologi, misalnya mengalami sakit, cacat tubuh atau perkembangan yang tidak sempurna, dan;

2. Faktor psikologis, misalnya: intelegensi, motivasi, persepsi, sikap, bakat, kemandirian, dan lain-lain.

Faktor eksternal meliputi, keluarga, lingkungan, guru, masyarakat, sekolah serta peralatan belajar atau sarana belajar. Menurut Slameto (2010) faktor yang berasal dari luar diri siswa, seperti kurikulum, kompetensi profesionalisme guru, fasilitas belajar, lingkungan keluarga, lingkungan sekolah, lingkungan belajar. Dari uraian diatas disebutkan beberapa faktor yang mempengaruhi prestasi belajar diantaranya kemandirian belajar dan kelengkapan fasilitas belajar.

Ahmadi (2009) mengemukakan bahwa pembelajaran berpusat pada siswa tidak membatasi siswa untuk memperoleh pengetahuan hanya dari guru. Sebaliknya, mereka dibatasi oleh kemampuan mereka sendiri tentang kapan dan bagaimana mereka akan belajar. Saat ini, sekolah bergerak maju dengan menggunakan pendekatan yang berpusat pada siswa, dengan pendekatan ini, siswa lebih aktif terlibat dalam materi pelajaran, mereka lebih termotivasi sebagai peserta didik dan mereka belajar keterampilan lebih banyak terutama disiplin, komunikasi, dan kolaborasi kemampuan. Jadi, kemandirian seseorang dalam belajar akan menentukan arah belajar dan prestasi belajar seseorang. Kemandirian yang dimiliki siswa diharapkan dapat memanfaatkan waktu di sekolah dan di rumah dalam menggunakan keseluruhan sumber belajar baik sumber belajar tercetak maupun sumber belajar lainnya. Kemandirian belajar dicirikan dengan ketidak tergantungan terhadap orang lain, memiliki kepercayaan diri, berperilaku disiplin, memiliki rasa tanggung jawab, berperilaku berdasarkan inisiatif sendiri, dan melakukan kontrol diri. Apabila siswa mampu menerapkan ciri-ciri tersebut maka prestasi belajar siswa akan semakin baik. 
Fasilitas belajar merupakan sarana dan prasarana yang digunakan dalam proses pembelajaran. Abdullah (2004) mengatakan bahwa "fasilitas belajar dapat dikelompokkan menjadi dua yaitu sarana dan prasarana pendidikan. Sarana pendidikan adalah semua perangkat peralatan, bahan dan perabot yang secara langsung digunakan dalam proses pendidikan di sekolah. Sedangkan prasarana pendidikan adalah semua perangkat kelengkapan dasar yang secara tidak langsung menunjang pelaksanaan proses pendidikan di sekolah. Agar suatu pendidikan yang dikembangkan tetap baik, maka perlu diadakan dan diciptakan suatu fasilitas yang dapat membantu dan mendorong hasil belajar siswa, seperti dalam UndangUndang No. 20 Tahun 2013 pasal 45 ayat 1 tentang fasilitas pendidikan yang menyatakan "Setiap satuan pendidikan baik formal maupun non formal menyediakan fasilitas yang memenuhi keperluan pendidikan sesuai dengan pertumbuhan dan perkembangan potensi fisik, kecerdasan intelektual, sosial, emosional, dan kewajiban peserta didik". Fasilitas belajar akan berpengaruh tehadap prestasi belajar siswa, semakin baik fasilitas belajar maka prestasi belajar siswa juga akan semakin baik. Adanya fasilitas seperti: ruang belajar, penerangan yang cukup, sirkulasi udara (ventilasi), buku-buku pegangan, dan kelengkapan belajar adalah faktor yang dapat mempengaruhi prestasi belajar siswa.

Menurut Rifa'I dan Chatarina (2010) belajar merupakan proses penting bagi perubahan perilaku setiap orang dan belajar itu mencakup segala sesuatu yang dipikirkan dan dikerjakan oleh seseorang. Gagne dalam Slameto (2010) memberikan dua definisi dalam masalah belajar, yaitu:

1. Belajar adalah suatu proses untuk memperoleh motivasi dalam pengetahuan, keterampilan, kebiasaan dan tingkah laku;

2. Belajar adalah penguasaan pengetahuan atau keterampilan yang diperoleh dari instruksi.

Beberapa pendapat tersebut dapat disimpulkan bahwa belajar adalah sesuatu proses yang diawali dengan pemahaman yang baik mengenai suatu hal sehingga menghasilkan suatu perubahan perilaku ke arah yang lebih baik, dan untuk mengetahui seberapa jauh perubahan yang terjadi perlu adanya penilaian. Hasil dari penilaian inilah yang disebut prestasi belajar. 
Prestasi belajar matematika merupakan hasil yang dicapai oleh siswa setelah mengikuti proses pembelajaran mata pelajaran matematika dalam jangka waktu tertentu yang dinyatakan dalam bentuk nilai. Siswa yang belajar hanya akan sampai pada perolehan hasil belajar apabila mengalami sendiri dalam proses perolehan hasil belajar tersebut. Kemandirian belajar merupakan kemampuan seseorang untuk melakukan aktivitas belajarnya atas pilihan, kemauan, dan tanggung jawabnya sendiri tanpa bergantung pada orang lain. Siswa dengan kemandirian belajar yang tinggi akan memiliki kualitas belajar matematika yang tinggi sehingga dapat meningkatkan prestasi belajar matematika.

Walgito (2004) mengemukakan bahwa, "persepsi merupakan suatu proses yang didahului oleh pengindraan yaitu merupakan proses yang berwujud diterimanya stimulus oleh individu melalui alat reseptornya. Proses psikologis dan hasil pengindraan tersebut membentuk proses berpikir. Di samping itu sifat suka dan tidak suka, senang tidak senang terhadap suatu objek akan menimbulkan gambaran dalam pembentukan persepsi”. Persepsi siswa dalam penelitian ini yaitu tentang kemandirian belajar dan kelengkapan fasilitas belajar yang kemudian di interpretasikan sehingga akan menimbulkan respon pada siswa dimana respon tersebut bergantung pada sikap siswa itu sendiri apakah siswa akan menanggapi stimulus tersebut secara positif ataukah negatif. Jadi apabila persepsi siswa tentang kemandirian belajar dan kelengkapan fasilitas belajar positif maka siswa akan termotivasi untuk melakukan kegiatan belajar dengan tujuan untuk meningkatkan prestasi belajarnya di sekolah.

Apabila siswa didukung kemandirian belajar yang tinggi serta fasilitas belajar yang baik membuat siswa memiliki kualitas belajar yang semakin baik sehingga dapat menghasilkan prestasi belajar matematika yang tinggi. Berdasarkan uraian di atas, penelitian ini bertujuan menguji persepsi siswa tentang kemandirian belajar dan kelengkapan fasilitas belajar terhadap prestasi belajar matematika siswa kelas VII di SMP Negeri 1 Kalaena Kiri Kabupaten Luwu Timur.

\section{B. Metode Penelitian}

Penelitian ini menggunakan metode ex-post facto. Peneliti dalam hal ini menelusuri hubungan sebab akibat (kausal) dan menguji hipotesis yang telah 
dirumuskan sebelumnya antara variabel bebas atau variabel penyebab (X) yakni kemandirian belajar dan kelengkapan fasilitas belajar dengan variabel terikat (Y) yakni prestasi belajar matematika yang diarahkan untuk menguji secara deskriptif asosiatif, deskriptif artinya mendeskripsikan variabel kemandirian belajar $\left(\mathrm{X}_{1}\right)$, kelengkapan fasilitas belajar $\left(\mathrm{X}_{2}\right)$ dan prestasi belajar matematika siswa $(\mathrm{Y})$, sedangkan asosiatif maknanya mencari hubungan antara variabel kemandirian belajar $\left(\mathrm{X}_{1}\right)$, kelengkapan fasilitas belajar $\left(\mathrm{X}_{2}\right)$ dan prestasi belajar matematika $\operatorname{siswa}(\mathrm{Y})$.

Hubungan antara variabel tersebut dapat digambarkan sebagai berikut.

Indikator kemandirian belajar $\left(\mathrm{X}_{1}\right)$ :

1. Siswa sadar akan pentingnya belajar

2. Mampu berpikir alternatif dalam belajar

3. Siswa sadar akan tanggung jawabnya yaitu belajar

4. Memiliki tujuan jangka panjang

5. Ada keberanian dalam menyelesaikan masalah dalam belajar Sumber: (Soeparwoto, 2005)

Indikator Fasilitas Belajar $\left(\mathrm{X}_{3}\right)$ :

1. Gedung Sekolah

2. Ruang Kelas

3. Perpustakaan Sekolah

4. Alat Bantu Belajar dan Media Pengajaran

5. Buku Pelajaran

Sumber: (Djamarah, 2011)

Gambar 1. Skema keterkaitan variabel penelitian

Populasi dalam penelitian ini adalah seluruh siswa kelas VII SMP Negeri

1 Kalaena Kiri Kabupaten Luwu Timur yang berjumlah 104 siswa. Sampel yang diambil adalah sebagian siswa berjumlah 83 siswa. Penelitian ini menggunakan teknik pengambilan sampel probability sampling dengan proportional random sampling. Probability sampling adalah teknik pengambilan sampel yang memberi peluang yang sama bagi setiap unsur(anggota) populasi untuk dipilih menjadi anggota sampel. Penentuan besarnya sampel pada penelitian ini adalah dengan menggunakan rumus dari Slovin. 
Tabel 1. Data siswa kelas VII SMP Neg. 1 Kalaena Kiri tahun pelajaran $2017 / 2018$

\begin{tabular}{ccc}
\hline No & Kelas & Jumlah Siswa \\
\hline 1. & Kelas VII A & 27 \\
2. & Kelas VII B & 26 \\
3. & Kelas VII C & 26 \\
4. & Kelas VII D & 25 \\
\hline
\end{tabular}

Sumber: Dokumen SMP Negeri 1 Kalaena Kiri Kabupaten Luwu Timur (2018)

Instrumen yang digunakan dalam pengumpulan data adalah angket atau kuesioner dengan menggunakan instrumen yang telah dikembangkan oleh peneliti kemudian instrumen diperiksa kelengkapan dan diinput dalam program Ms. Excel. Instrumen yang tidak lengkap tidak diinput. Setelah data ditabulasi dilakukan pemeriksaan atas data tersebut termasuk data-data yang out of range, missing dan sebagainya. Data pencilan (outlier) akan dipertimbangkan dalam analisis. Sehingga, total sampel penelitian sebanyak 83 unit dan dinyatakan clean.

Tabel 2. Spesifiksi butir-butir tes variabel prestasi belajar matematika (Y)

\begin{tabular}{|c|c|c|c|c|c|}
\hline \multirow[t]{2}{*}{ No } & \multirow[t]{2}{*}{ Kompetensi Dasar dan Indikator } & \multirow{2}{*}{$\begin{array}{l}\text { No } \\
\text { Butir }\end{array}$} & \multicolumn{3}{|c|}{$\begin{array}{l}\text { Domain } \\
\text { Kongnitif }\end{array}$} \\
\hline & & & $\mathrm{C} 1$ & $\mathrm{C} 2$ & $\mathrm{C} 3$ \\
\hline \multicolumn{6}{|c|}{ Menjelaskan rasio dua besaran (satuannya sama dan berbeda) } \\
\hline 1 & Menghitung dua besaran yang satuannya berbeda & 1 & & $\sqrt{ }$ & $\sqrt{ }$ \\
\hline \multicolumn{6}{|c|}{ Menyelesaikan masalah yang berkaitan dengan rasio dua besaran } \\
\hline 2 & $\begin{array}{l}\text { Menyelesaikan masalah kontekstual yang berkaitan } \\
\text { dengan rasio dua besaran (satuan yang sama dan } \\
\text { berbeda) }\end{array}$ & 2 & & $\sqrt{ }$ & $\sqrt{ }$ \\
\hline
\end{tabular}

Menganalisis aritmetika sosial (penjualan, pembelian, potongan, keuntungan, kerugian, bunga tunggal, persentase, bruto, neto, tara)

a. Menghitung harga penjualan dan harga pembelian jika keuntungan atau kerugian diketahui

b. Menghitung besar keuntungan atau kerugian serta impas jika harga pembelian dan penjualan diketahui

Menyelesaikan masalah berkaitan dengan aritmetika sosial (penjualan, pembelian, potongan, keuntungan, kerugian, bunga tunggal, persentase, bruto, neto, tara)

Menyelesaikan permasalahan sehari-hari yang melibatkan nilai keseluruhan, unit, sebagian, harga jual, harga beli, persentase untung dan persentase 4 rugi

Menyelesaikan masalah yang berkaitan dengan sudut dan garis Menggunakan sifat-sifat sudut dan garis untuk

6 menyelesaikan soal-soal yang berkaitan dengan sudut dan garis

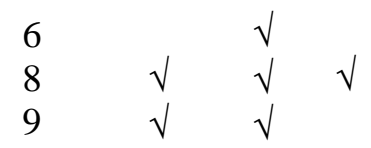

Menganalisis Hubungan antar sudut sebagai akibat dari dua garis sejajar yang dipotong oleh 
garis transversal

$\begin{array}{llllllll}\text { Menemukan sifat sudut jika dua } & \text { garis } & \text { sejajar } & 7 & \sqrt{ } & \sqrt{ } \\ \text { dipotong garis ketiga (garis lain) }\end{array}$

Manganalisis berbagai bangun datar segiempat (persegi, persegi panjang, belah ketupat, jajar genjang, trapesium, dan layang-layang) dan segitiga berdasarkan sisi, sudut, dan hubungan antar sisi dan antar sudut.

8 Mengenal dan memahami bangun datar segiempat dan segitiga

Sumber: SMP Negeri 1 Kalaena Kiri Kabupaten Luwu Timur

Skala yang digunakan pada penelitian ini adalah skala ordinal atau linkert. Menurut Sugiyono (2010) jawaban setiap item instrument yang menggunakan skala linkert mempunyai susunan seperti: sangat setuju, setuju, kurang setuju, tidak setuju dan sangat tidak setuju. Pada setiap pernyataan dalam instrument disediakan lima pilihan jawaban dengan skor masing-masing sebagai berikut:
a. Skor 5 jika jawaban Sangat Setuju
b. Skor 4 jika jawaban Setuju
c. Skor 3 jika jawaban Kurang Setuju
d. Skor 2 jika jawaban Tidak Setuju
e. Skor 1 jika jawaban Sangat Tidak Setuju

Tabel 3. Kisi-kisi instrument variabel kemandirian belajar $\left(\mathrm{X}_{2}\right)$

\begin{tabular}{cllc}
\hline No & \multicolumn{1}{c}{ Indikator } & \multicolumn{1}{c}{ Nomor Item } & Jumlah \\
\hline 1 & Siswa sadar akan pentingnya belajar & $16,17,18$ & 3 \\
2 & Mampu berpikir alternatif dalam belajar & $19,20,21$ & 3 \\
3 & Memiliki rasa tanggung jawab & $22,23,24$ & 3 \\
4 & Memiliki tujuan jangka panjang & $25,26,27$ & 3 \\
5 & Ada keberanian dalam menyelesaikan & 28,29 & 2 \\
\hline & masalah & 14 & 14 \\
\hline
\end{tabular}

Sumber: Djamarah (2010)

Tabel 4. Kisi-kisi instrument variabel kelengkapan fasilitas belajar $\left(\mathrm{X}_{3}\right)$

\begin{tabular}{cllc}
\hline No & \multicolumn{1}{c}{ Indikator } & \multicolumn{1}{c}{ Nomor Item } & Jumlah \\
\hline 1 & Gedung Sekolah & $30,31,32$ & 3 \\
2 & Ruang Kelas & $33,34,35$ & 3 \\
3 & Perpustakaan Sekolah & $36,37,38$ & 3 \\
4 & Alat bantu dan media pembelajaran & 39,40 & 2 \\
5 & Buku pelajaran & 40,41 & 2 \\
\hline \multicolumn{2}{c}{ Jumlah Item Keseluruhan } & 13 & 13 \\
\hline
\end{tabular}

Sumber: Djamarah (2010)

Dalam penelitian ini menggunakan analisis data statistika deskriptif dan statistika inferensial. Analisis statistika deskriptif digunakan untuk 
mendeskripsikan karakteristik masing-masing indikator dalam setiap variabel agar lebih mudah memahami pengukuran pada variabel yang diungkapkan. Kategori untuk variabel dikelompokkan menjadi 5 (lima) yaitu sangat setuju, setuju, kurang setuju, tidak setuju dan sangat tidak setuju. Sementara analisis statistik inferensial yang digunakan dalam penelitian ini adalah analisis regresi berganda. Analisis regresi berganda adalah hubungan secara linier dua atau lebih variabel independen $\left(\mathrm{X}_{1}, \mathrm{X}_{2}, \ldots, \mathrm{Xn}\right)$ dengan variabel dependen $(\mathrm{Y})$. Pengujian hipotesis dalam penelitian ini adalah uji parsial (uji t). Proses pengolahan data agar bisa secara cepat dan tepat maka pengolahan datanya dilakukan melalui program SPSS, apabila $<5 \%(0,05)$ maka $\mathrm{H}_{0}$ ditolak dan $\mathrm{H}_{1}$ diterima, berarti bahwa variabel bebas dapat menerangkan variabel terikat. Sebaliknya apabila > 5\% $(0,05)$ maka $\mathrm{H}_{0}$ diterima dan $\mathrm{H}_{1}$ ditolak, berarti bahwa variabel bebas tidak dapat menerangkan variabel terikatnya secara individual.

\section{Hasil Pembahasan}

\section{Pengaruh Persepsi Siswa tentang Kemandirian Belajar terhadap Prestasi Belajar Matematika Siswa}

Kemandirian belajar diukur dengan menggunakan instrumen berupa angket kemandirian belajar yang terdiri dari 14 item pernyataan. Berdasarkan skor variabel kemandirian belajar $\left(\mathrm{X}_{1}\right)$ siswa kelas VII SMP Negeri 1 Kalaena Kiri di kabupaten Luwu Timur diperoleh hasil analisis statistika deskriptif sebagaimana disajikan pada tabel dibawah ini:

Tabel 5. Distibusi frekuensi, presentase, dan kategori untuk variabel kemandirian belajar

\begin{tabular}{|c|c|c|c|c|}
\hline No & Skor & Frekuensi & Persentasi (\%) & Kategori \\
\hline 1 & $14 \leq K B<28.5$ & 0 & 0 & Sangat Rendah \\
\hline 2 & $28.6 \leq K B<37.5$ & 11 & 13.25 & Rendah \\
\hline 3 & $37.6 \leq K B<46.5$ & 9 & 10.85 & Sedang \\
\hline 4 & $46.6 \leq K B<55.5$ & 25 & 30.12 & Tinggi \\
\hline 5 & $55.6 \leq K B \leq 70$ & 38 & 45.78 & Sangat Tinggi \\
\hline & Jumlah & 83 & 100 & \\
\hline
\end{tabular}

Berdasarkan Tabel 5, diperoleh informasi bahwa tidak satupun siswa yang memperoleh skor dalam kategori sangat rendah. Secara umum skor kemandirian belajar siswa kelas VII SMP Negeri 1 Kalaena Kiri berada pada kategori tinggi. 
Ini menunjukkan bahwa siswa memiliki persepsi, harapan, perasaan dan kesediaan atau kesiapan yang cukup kuat dalam belajar matematika.

Uji hipotesis untuk variabel kemandirian belajar diperoleh hasil untuk variabel Nilai $F_{\text {Hitung }}$ dari tabel anova sebesar $=198,389$ dan nilai $F_{\text {Tabel }}$ dari tabel $\mathrm{F}=3.96$. Dari tabel anova nilai probabilitas $($ sig $)=0,001$ dan nilai taraf signifikan $\alpha=0,05$. Dari hasil pengujian menunjukkan bahwa $F_{\text {Hitung }}>F_{\text {Tabel }}$ dan 0,001 > 0,05 .

Kemandirian belajar dengan prestasi belajar matematika siswa kuat positif, yaitu $\mathrm{r}=0.843$. karena nilai $\mathrm{r}$ positif positif maka hubungan antara kemandirian belajar dengan prestasi belajar matematika siswa searah yang berarti semakin tinggi kemandirian belajar maka semakin tinggi pula perstasi belajar matematika dari siswa tersebut. Di mana kontribusi yang disumbangkan kemandirian belajar terhadap prestasi belajar matematika siswa sebesar $71 \%(R$ Square $=0.710)$.

Jika kemandirian sudah tertanam di setiap diri para peserta didik tentunya akan berimplikasi pada pendidikan. Mereka sebagai subjek pendidikan dan mempunyai sikap kemandirian tentunya akan membawa dampak baik bagi masa depan pendidikan. Manfaat kemandirian menurut Abdullah (2004) yaitu menumbuhkan kesadaran dan tanggung jawab yang lebih besar dalam membuat pelajaran menjadi bermakna terhadap dirinya sendiri, menumbuhkan rasa lebih penasaran untuk mencoba hal-hal baru, dan siswa akan memsayang permasalahan sebagai tantangan yang baru dihadapi, minat belajar terus berkembang dan pembelajaran lebih menyenangkan dan mereka menjadi lebih termotivasi dan gigih, mandiri, disiplin diri, percaya diri dan berorientasi pada tujuan.

\section{Pengaruh Persepsi Siswa tentang Kelengkapan Fasilitas Belajar terhadap Prestasi Belajar Matematika Siswa}

Kelengkapan fasilitas belajar diukur dengan menggunakan instrumen berupa angket yang terdiri dari 13 item pernyataan. Berdasarkan skor variabel kelengkapan fasilitas belajar $\left(\mathrm{X}_{2}\right)$ siswa diperoleh hasil analisis statistika deskriptif sebagaimana disajikan pada tabel berikut ini: 
Tabel 6. Distibusi frekuensi, presentase, dan kategori untuk variabel kelengkapan fasilitas belajar

\begin{tabular}{ccccc}
\hline No & Skor & Frekuensi & Persentasi $(\%)$ & Kategori \\
\hline 1 & $13 \leq F B<26.1$ & 0 & 0.00 & Sangat Rendah \\
2 & $26.2 \leq F B<34.7$ & 13 & 15.66 & Rendah \\
3 & $34.8 \leq F B<43.3$ & 5 & 6.03 & Sedang \\
4 & $43.4 \leq F B<51.9$ & 17 & 20.48 & Tinggi \\
5 & $52 \leq F B \leq 65$ & 48 & 57.83 & Sangat Tinggi \\
\hline & Jumlah & 83 & 100 & \\
\hline
\end{tabular}

Sampel: 83 siswa

Berdasarkan tabel diperoleh informasi bahwa tidak satupun siswa yang memperoleh skor dalam kategori sangat rendah. Secara umum skor kelengkapan fasilitas belajar siswa pada kategori sangat tinggi. Tingginya skor kelengkapan fasilitas belajar berarti siswa memiliki persepsi yang positif terhadap belajar matematika dimana ini disebabkan karena SMP Negeri 1 Kalaena Kiri merupakan satu-satunya sekolah negeri yang berada di Kecamatan Kalena Kiri Kabupaten Luwu Timur sehingga pemerintah umumnya dan kepala sekolah pada khususnya sangat memperhatikan keadaan dan kebutuhan para siswa di sekolah, dapat dilihat dari sarana dan prasarana sekolah berupa jumlah guru yang memadai, kelengkapan ruangan berupa ruang belajar, penerangan yang cukup, sirkulasi udara (ventilasi), koleksi buku yang lengkap di perpustakaan, laboratorium, musholah, lapangan sepak bola, lapangan basket dan taman sekolah yang begitu baik.

Variabel kelengkapan fasilitas belajar melalui uji hipotesis diperoleh nilai $F_{\text {Hitung }}$ dari tabel anova sebesar $=72,696$ dan nilai $F_{\text {Tabel }}$ dari tabel $\mathrm{F}=3.96$. Tabel anova nilai probabilitas (sig) $=0,001$ dan nilai taraf signifikan $\alpha=0,05$. Dari hasil pengujian menunjukkan bahwa $F_{\text {Hitung }}>F_{\text {Tabel }}$ dan 0,001 $>0,05$.

Kelengkapan fasilitas belajar dengan prestasi belajar matematika siswa kuat positif, yaitu $r=0.688$. karena nilai $r$ positif positif maka hubungan antara kelengkapan fasilitas belajar dengan prestasi belajar matematika siswa searah yang berarti semakin tinggi kelengkapan fasilitas belajar maka semakin tinggi pula prestasi belajar matematika dari siswa tersebut. Di mana kontribusi yang disumbangkan kelengkapan fasilitas belajar terhadap prestasi belajar matematika siswa sebesar 47,3\% ( $R$ Square $=0.473)$. 
Berdasarkan hasil penelitian dapat disimpulkan bahwa jika kelengkapan fasilitas belajar di rumah dapat terpenuhi dengan baik, maka akan membantu kegiatan belajar siswa, sehingga dapat meningkatkan prestasi belajar siswa. Uraian di atas didukung oleh Slameto (2003), yang mengatakan bahwa "untuk dapat belajar dengan efektif, diperlukan lingkungan fisik yang baik dan teratur. Fasilitas belajar akan berpengaruh tehadap prestasi belajar siswa, semakin baik fasilitas belajar maka prestasi belajar siswa juga akan semakin baik. Adanya ruang belajar, penerangan yang cukup, sirkulasi udara (ventilasi), buku-buku pegangan, dan kelengkapan belajar adalah faktor yang dapat mempengaruhi prestasi belajar siswa.

\section{Pengaruh Persepsi Siswa secara bersama antara Kemandirian Belajar dan} Kelengkapan Fasilitas Belajar terhadap Prestasi Belajar Matematika Siswa

Berdasarkan skor variabel prestasi belajar matematika (Y) diperoleh hasil analisis statistika deskriptif sebagaimana disajikan pada tabel berikut ini:

Tabel 7. Distibusi frekuensi, presentase, dan kategori untuk variabel prestasi belajar matematika

\begin{tabular}{ccccc}
\hline No & Skor & Frekuensi & Persentasi $(\%)$ & Kategori \\
\hline 1 & $0 \leq P B<40$ & 2 & 2.41 & Sangat Rendah \\
2 & $41 \leq P B<60$ & 11 & 13.25 & Rendah \\
3 & $61 \leq P B<75$ & 9 & 10.84 & Sedang \\
4 & $76 \leq P B<90$ & 49 & 59.04 & Tinggi \\
5 & $91 \leq P B<100$ & 12 & 14.46 & Sangat Tinggi \\
\hline \multicolumn{7}{c}{ Jumlah } & 83 & 100 & \\
\hline
\end{tabular}

Berdasarkan Tabel 7, secara umum skor prestasi belajar siswa berada pada kategori tinggi. Tingginya prestasi belajar matematika pada siswa kelas VII A SMP Negeri 1 Kalaena Kiri disebabkan oleh kemandirian belajar yang tinggi serta fasilitas belajar yang baik membuat siswa memiliki kualitas belajar yang semakin baik sehingga dapat menghasilkan prestasi belajar matematika yang tinggi. Secara garis besar kemandirian siswa dan kelengkapan fasilitas belajar yang tinggi sangat membantu siswa dalam belajar matematika sehingga dapat diperoleh prestasi belajar yang baik pula.

Uji hipotesis untuk variabel kemandirian belajar diperoleh hasil untuk variabel Nilai $F_{\text {Hitung }}$ dari tabel anova sebesar $=198,389$ dan nilai $F_{\text {Tabel }}$ dari tabel $\mathrm{F}=3.96$. Dari tabel anova nilai probabilitas $($ sig $)=0,001$ dan nilai taraf signifikan 
$\alpha=0,05$. Dari hasil pengujian menunjukkan bahwa $F_{\text {Hitung }}>F_{\text {Tabel }}$ dan $0,001>$ 0,05 .

Kemandirian belajar dengan prestasi belajar matematika siswa kuat positif, yaitu $r=0.843$. karena nilai $r$ positif positif maka hubungan antara kemandirian belajar dengan prestasi belajar matematika siswa searah yang berarti semakin tinggi kemandirian belajar maka semakin tinggi pula perstasi belajar matematika dari siswa tersebut. Di mana kontribusi yang disumbangkan kemandirian belajar terhadap prestasi belajar matematika siswa sebesar $71 \%(R$ Square $=0.710)$.

Variabel kelengkapan fasilitas belajar melalui uji hipotesis diperoleh nilai $F_{\text {Hitung }}$ dari tabel anova sebesar $=72,696$ dan nilai $F_{\text {Tabel }}$ dari tabel $\mathrm{F}=3.96$. Tabel anova nilai probabilitas $($ sig $)=0,001$ dan nilai taraf signifikan $\alpha=0,05$. Dari hasil pengujian menunjukkan bahwa $F_{\text {Hitung }}>F_{\text {Tabel }}$ dan $0,001>0,05$.

Kelengkapan fasilitas belajar dengan prestasi belajar matematika siswa kuat positif, yaitu $r=0.688$. karena nilai $r$ positif positif maka hubungan antara kelengkapan fasilitas belajar dengan prestasi belajar matematika siswa searah yang berarti semakin tinggi kelengkapan fasilitas belajar maka semakin tinggi pula prestasi belajar matematika dari siswa tersebut. Di mana kontribusi yang disumbangkan kelengkapan fasilitas belajar terhadap prestasi belajar matematika siswa sebesar 47,3\% ( $R$ Square $=0.473)$.

Hasil pengujian dari kedua variabel menunjukkan bahwa $F_{\text {Hitung }}>F_{\text {Tabel }}$ dan 0,001 > 0,05 maka $\mathrm{H}_{0}$ ditolak sehingga diperoleh kesimpulan bahwa terdapat kemandirian belajar dan kelengkapan fasilitas belajar terhadap prestasi belajar matematika siswa, dengan kata lain model regresi sederhana dapat digunakan untuk meprediksi prestasi belajar siswa kelas VII di SMP Negeri 1 Kalaena Kiri Kabupaten Luwu Timur yang dipengaruhi oleh kemandirian belajar dan kelengkapan fasilitas belajar.

Prestasi belajar siswa dapat dijadikan tolak ukur untuk menilai keberhasilan proses pembelajaran di sekolah. Tu'u (2004) menyatakan "prestasi belajar adalah penguasaan pengetahuan dan ketrampilan yang dikembangkan oleh mata pelajaran lazimnya ditunjukan dengan nilai tes atau angka nilai yang diberikan oleh guru". Dari pernyataan tersebut dapat disimpulkan bahwa prestasi 
belajar siswa berfokus pada nilai atau angka yang dicapai siswa dalam proses pembelajaran di sekolah, utamanya nilai yang dilihat dari sisi kognitif, karena ranah inilah yang sering dinilai oleh guru untuk melihat penguasaan materi sebagai ukuran pencapaian hasil belajar siswa. Dengan demikian, disimpulkan bahwa semakin tinggi kemandirian belajar dan kelengkapan fasilitas belajar matematika siswa maka akan semakin tinggi pula prestasi belajar matematika siswa.

\section{Kesimpulan}

Berdasarkan pembahasan hasil penelitian, maka dapat diambil kesimpulan dari penelitian ini adalah sebagai berikut :

1. Ada pengaruh positif dan signifikan antara kemandirian belajar terhadap prestasi belajar matematika siswa, berarti hipotesis diterima, kemandirian belajar memiliki hubungan dengan prestasi belajar matematika siswa kelas VII semester genap di SMP Negeri 1 Kalaena Kiri tahun pelajaran $2017 / 2018$

2. Ada pengaruh positif dan signifikan antara kelengkapan fasilitas belajar terhadap prestasi belajar matematika siswa, berarti hipotesis diterima, kelengkapan fasilitas belajar di rumah memiliki hubungan dengan prestasi belajar matematika siswa kelas VII semester genap di SMP Negeri 1 Kalaena Kiri tahun pelajaran 2017/2018.

3. Ada pengaruh positif dan signifikan secara bersama antara persepsi siswa tentang kemandirian belajar dan kelengkapan fasilitas belajar terhadap prestasi belajar matematika siswa berarti hipotesis diterima, persepsi siswa tentang kemandirian belajar dan kelengkapan fasilitas belajar memiliki hubungan dengan prestasi belajar matematika siswa kelas VII semester genap di SMP Negeri 1 Kalaena Kiri tahun pelajaran 2017/2018.

\section{Daftar Pustaka}

Abdullah, M. H. 2004. Developing Self-Directed Learners. Portland: Northwest Regional Laboratory.

Ahmadi, A. 2009. Psikologi Umum. Surabaya: Bina Ilmu. 
Gagne dan Slameto. 2010. Belajar dan Faktor-faktor yang Mempengaruhinya. Jakarta: Rineka Cipta.

Rifa'i, A. dan Chatarina, T.A. 2010. Psikologi Pendidikan. Semarang: UNNES PRESS.

Slameto. 2003. Belajar dan Faktor-Faktor yang Mempengaruhinya. Jakarta: Rineka Cipta.

Slameto. 2010. Belajar dan Faktor-faktor yang Mempengaruhinya. Jakarta: Rineka Cipta.

Sugiyono. 2010. Metode Penelitian Pendidikan. Bandung: Alfabeta.

Tu’u, T. 2004. Peran Disiplin pada Perilaku dan Prestasi Siswa. Jakarta: Gramedia Grasindo.

Undang-undang No. 20 tahun 2008 tentang guru dan dosen.

Undang-Undang No. 20 Tahun 2013 pasal 45 ayat 1 tentang fasilitas pendidikan.

Walgito, B. 2004. Pengantar Psikologi Umum. Yogyakarta: CV Andi Offset. 